MaPan : Jurnal Matematika dan Pembelajaran

p-ISSN: 2354-6883 ; e-ISSN: 2581-172X

Volume 6, No 1, June 2018 (11-19)

DOI: https://doi.org/10.24252/mapan.2018v6n1a2

\title{
ETHNOMATHEMATICS: EXPLORING THE ACTIVITIES OF DESIGNING KEBAYA KARTINI
}

\author{
Maryati1), Rully Charitas Indra Prahmana2) \\ 1SMP Muhammadiyah 1 Tepus Gunungkidul, Yogyakarta \\ 2Universitas Ahmad Dahlan, Jl. Pramuka Kav. 5, Pandeyan, Yogyakarta \\ E-mail: maryati1708050021@webmail.uad.ac.id ${ }^{1}$, , rully.indra@mpmat.uad.ac.id ${ }^{2}$
}

Submitted: 01-05-2018, Revised: 30-05-2018, Accepted: 30-05-2018

\begin{abstract}
:
The study aims to explore the correlation between mathematics and culture, especially in the activities of designing Kebaya Kartini. This research uses ethnography approach, that is an empirical and theoretical approach to get the description and deep analysis of a culture based on the field note obtained from the data collection. The result shows the activities of designing Kebaya Kartini have the concept of mathematics, such as the angle, measure, and integer operations.
\end{abstract}

Keywords: Ethnomathematics, Kebaya Kartini, Ethnography

\section{ETNOMATEMATIKA: MENGEKSPLORASI KEGIATAN MERANCANG KEBAYA KARTINI}

\begin{abstract}
Abstrak:
Tujuan dari penelitian ini adalah untuk mengeksplorasi hubungan antara matematika dengan budaya, khususnya dalam kegiatan merancang kebaya kartini. Penelitian ini menggunakan pendekatan etnografi yang merupakan sebuah pendekatan empiris dan teoritis untuk mendapatkan gambaran dan analisis mendalam tentang sebuah budaya berdasarkan catatan lapangan yang telah diperoleh dari hasil pengumpulan data. Hasil penelitian ini menunjukkan bahwa dalam kegiatan merancang kebaya kartini memiliki berbagai konsep matematika, seperti sudut, pengukuran, dan operasi bilangan bulat.
\end{abstract}

Kata Kunci: Etnomatematika, Kebaya Kartini, Etnografi

How to Cite: Maryati \& Prahmana, R.C.I. (2018). Ethnomathematics: Exploring the Activities of Designing Kebaya Kartini. MaPan : Jurnal Matematika dan Pembelajaran, 6 (1), 11-19.

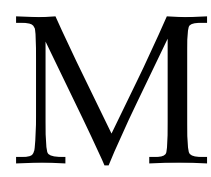
athematics is one of the most important subjects in the education system of Indonesia and study at all levels of education in Indonesia, from elementary school to university (Tanujaya, et al. 2017). Furthermore, mathematics is a necessary branch of knowledge required 
for students moreover required by everyone in daily activities to develop the ability of logical, systematic, critical thinking of students, and to support their learning success in the future (Niess, 2005; Runisah, et al. 2017; Prahmana and Kusumah, 2016). On the other hand, mathematics is an inherent knowledge in the activities of life and very close to the culture in the context of the behavior or habit that has existed since ancient times and for generations (Prahmana, et al. 2012; Muhtadi, et al. 2017; Risdiyanti \& Prahmana, 2017). Therefore, mathematics could be said as the one of subject that is very important and needed in everyday life because it can increase students' thinking ability.

Ethnomathematics is the practice of mathematics in cultural groups (Haryanto, et al. 2017; D'Ambrosio, 1989). The cultural group referred to them is urban or rural communities, working groups, professional grade, students in groups, indigenous peoples, and other specific groups (Kusuma, et al. 2016). Whether consciously or unconsciously, all of the human activities are done based on an appropriate calculation that is suitable to the condition of nature where they live. There are some researches related to ethnomathematics (Abdullah, 2017; Zaenuri \& Dwidayati, 2018; Ditasona, 2018; Hariastuti, 2017; Sari, et al. 2018; Putri, 2017; Wahyuni \& Pertiwi, 2017; Sudirman, et al. 2017; Pratikno, 2018; Muchsin, et al. 2014). Abdullah (2017) explores the mathematics in perspective sundanese culture and Ditasona (2018) teaches mathematics using a motif gorga (ornament on Batak House). Furthermore, several researchers explore some context as a starting point in mathematics learning process, such as mathematics in Northern Coastal Areas of Java Island (Zaenuri \& Dwidayati, 2018), mathematics in the game of guessing the mangosteen (Hariastuti, 2017), mathemathics in traditional house culture Ogan Komering Ulu Sumatera coast (Sari, et al. 2018), mathematics in art Rebana (Putri, 2017), mathematics in veriety of Melayu ornamental (Wahyuni \& Pertiwi, 2017), mathematics in art Batik Indramayu (Sudirman, et al. 2017), mathematics in Bregada Prajurit Keraton Yogyakarta (Pratikno, 2018), invented strategies for partitive division on fractions using duration context (Muchsin, et al. 2014). Therefore, culture could be the context as the starting point in mathematics learning process.

When we study of Ethnomathematics, it does not mean we only examine the mathematical phenomenon and translated it into a formal mathematical concept (mathematical modeling). However, more than that, the way of thinking and the underlying values why a particular individual or group can have such an understanding like that is also interesting to learn 
(Arisetyawan, et al. 2014). Ethnomathematics has as its source the activities that a person/group performs and the knowledge they have resulting from the needs of their daily lives. It assumes dynamic sharing between activities and knowledge; values popular knowledge production; and proposes education as a process in which knowledge transmitted across generations (Biembengut, 2016). Ethnomathematics explores the interaction of academic and cultural ways to provide inclusive developmental programs for diverse populations served by educational institutions (Rosa, et al. 2016). The cultural mathematics of cultural groups is considered part of their life characteristics and developed by the cultural group and serves their natural interests, which derive from their social situation (Fouze \& Amit, 2018; Anderson, 1990). Therefore, teachers have a large influence over shaping the boundaries between the two fields of formal mathematics and Ethnomathematics and on the comprehensive integration of daily mathematical activities into mathematics.

Indonesia is one country in Asia with a population that is multicultural. One of them is the activity of design Kebaya. It is one of the traditional dresses in Indonesia. Kebaya is a dress with buttons open on the front and paired with traditional fabric. One type of Kebaya that exists in Indonesia is Kebaya Kartini (KK).

\section{METHOD}

The methodology used in this research belongs to the exploratory research methods, the research excavation. It means that the methods are to find and to know a phenomenon or event (concept or problem) with conducting an assessment of the symptoms (Gulo, 2000; Prahmana, 2017). Moreover, in the process using an ethnographic approach, is an empirical and theoretical approach, aiming to get a description and a thorough analysis of culture based on field research. How people organize their culture in mind and then use in life. Ethnographic tasks to finds and describe the organization of the mind (Spradley, 2007). The procedure of research conducted adopting ethnographic approach by Spradley (2007), includes the following steps: establish informants, conducting interviews with informants, making notes ethnographic, ask questions descriptive, analyzing the results of ethnographic interviews, create a domain analysis, asking questions of structural, conduct taxonomic analysis, and writing ethnography. 


\section{RESULT AND DISCUSSION}

The results showed that Ethnomathematics found in the design KK in LPK Nusa Indah Gunungkidul. Ethnomathematics in KK designing activities can be seen from the process of making patterns on the back, front, and hand. The figure 1 is a picture of KK, which consists of a pattern of the back, a pattern of the front, and a pattern the hand.

a. The angle

To start making a pattern, first have to drawing the angle of the elbow BAC (Figure 1 and 2).

b. Measure

To determine the size of KK, it should first be measured the length of the desired Kebaya, body width, back width, waist width, thigh width, arm length, arm width, and armpit.

c. Integer operation

The body size of the person who will use the $\mathrm{KK}$, the basis for calculating the size of the KK pattern to be made. To calculate the size of the pattern, the students are using the concept of fractional operation.

\section{To make a pattern of the back (Figure 1):}

We make the angle elbow BAC

$\mathrm{A}-\mathrm{B}=$ the length of kebaya $=36 \mathrm{~cm}$

$$
\begin{array}{ll}
\mathrm{A}-\mathrm{A} 1=2 \mathrm{~cm} & \mathrm{~A}-\mathrm{C}=1 / 2 \text { the width of the back } \\
\mathrm{A}-\mathrm{A} 2=7 \mathrm{~cm} & \mathrm{~A}-\mathrm{N}=1 / 3 \text { the length of kebaya }
\end{array}
$$

Pull a straight line right from the point $\mathrm{N}$ and $\mathrm{B}$

$$
\mathrm{N}-\mathrm{M}=1 / 4 \text { the body } \quad \text { B-E }=1 / 4 \text { waist }+2
$$

Pull a straight line bottom from the point $\mathrm{C}$ and $\mathrm{M}$

$\mathrm{C}-\mathrm{C} 1=3 \mathrm{~cm}$

Pull a line from the point $\mathrm{C} 1$ to point $\mathrm{A} 2$ then bend to point $\mathrm{A} 1$

$\mathrm{C} 1-\mathrm{K}=1 / 2$ armpit $-2 \mathrm{~cm}$

$\mathrm{B}-\mathrm{R}=20 \mathrm{~cm}$

R-R1 = $1 / 4$ thighs

Pull a straight line from the point $\mathrm{K}$ to point $\mathrm{E}$ and then from point $\mathrm{E}$ to point R1 


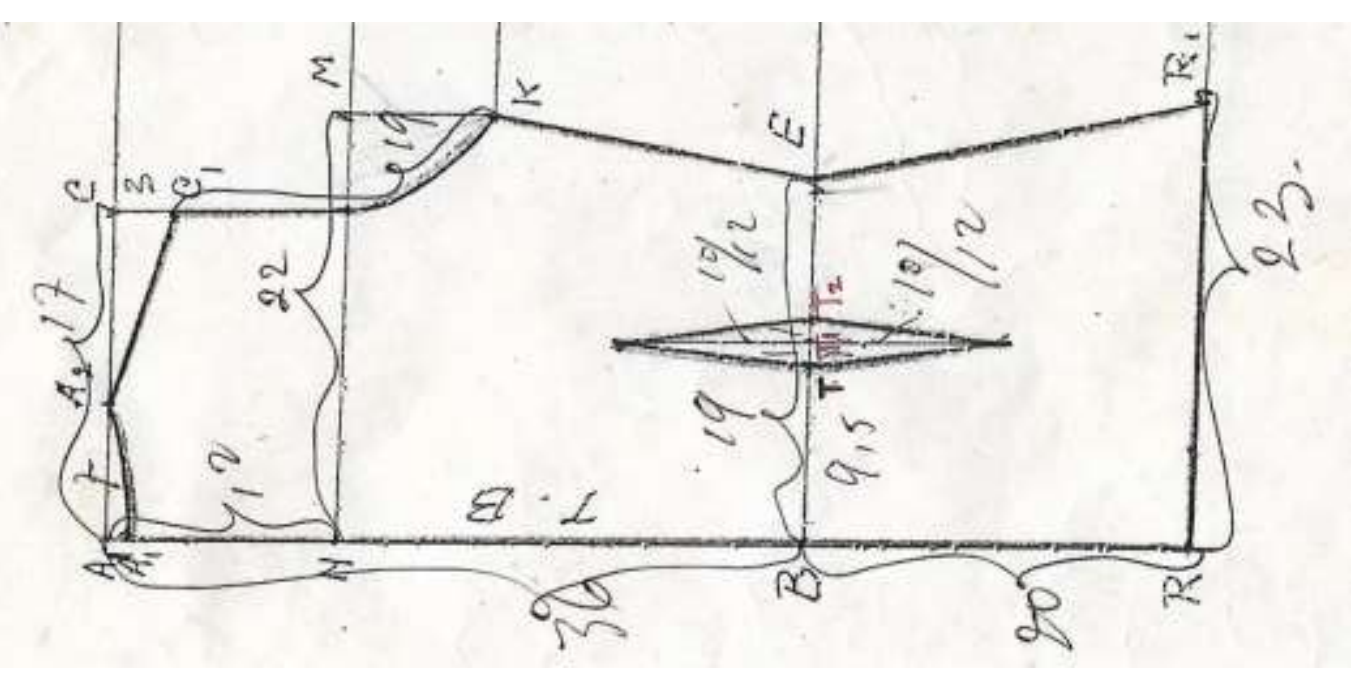

Figure 1. The Pattern of the Back

To make "kupnat" (the design of Kebaya Kartini) of the back (Figure 1):

$\mathrm{E}-\mathrm{T}=1 / 2 \mathrm{E}-\mathrm{B}$

$\mathrm{T}-\mathrm{T} 1=\mathrm{T} 1-\mathrm{T} 2=1 \mathrm{~cm}$

$\mathrm{T} 1-\mathrm{L}=10-12 \mathrm{~cm}$

\section{To make pattern of the front (Figure 2):}

Take the pattern of the back!

Pull a straight line right from the point $\mathrm{K}$.

Change based on pattern of the back:
$\mathrm{A}-\mathrm{A} 3=8 \mathrm{~cm}$
$\mathrm{E}-\mathrm{E} 1=1 \frac{1}{2} \mathrm{~cm}$
$\mathrm{A} 3-\mathrm{A} 4 / / \mathrm{A}-\mathrm{A} 2$
$\mathrm{B}-\mathrm{B} 1=3 \mathrm{~cm}$
$\mathrm{A} 3-\mathrm{A} 4=8 \mathrm{~cm}$
$\mathrm{C} 1-\mathrm{K} 1=1 / 2$ armpit $+2 \mathrm{~cm}$
$\mathrm{A} 3-\mathrm{A} 5=1 \frac{1}{1 / 2}-2 \mathrm{~cm}$
$\mathrm{R} 1-\mathrm{R} 2=2 \mathrm{~cm}$
$\mathrm{K}-\mathrm{K} 1=2 \mathrm{~cm}$
$\mathrm{R}-\mathrm{R} 3=3 \mathrm{~cm}$

To make "kupnat" same with a pattern of the back. 


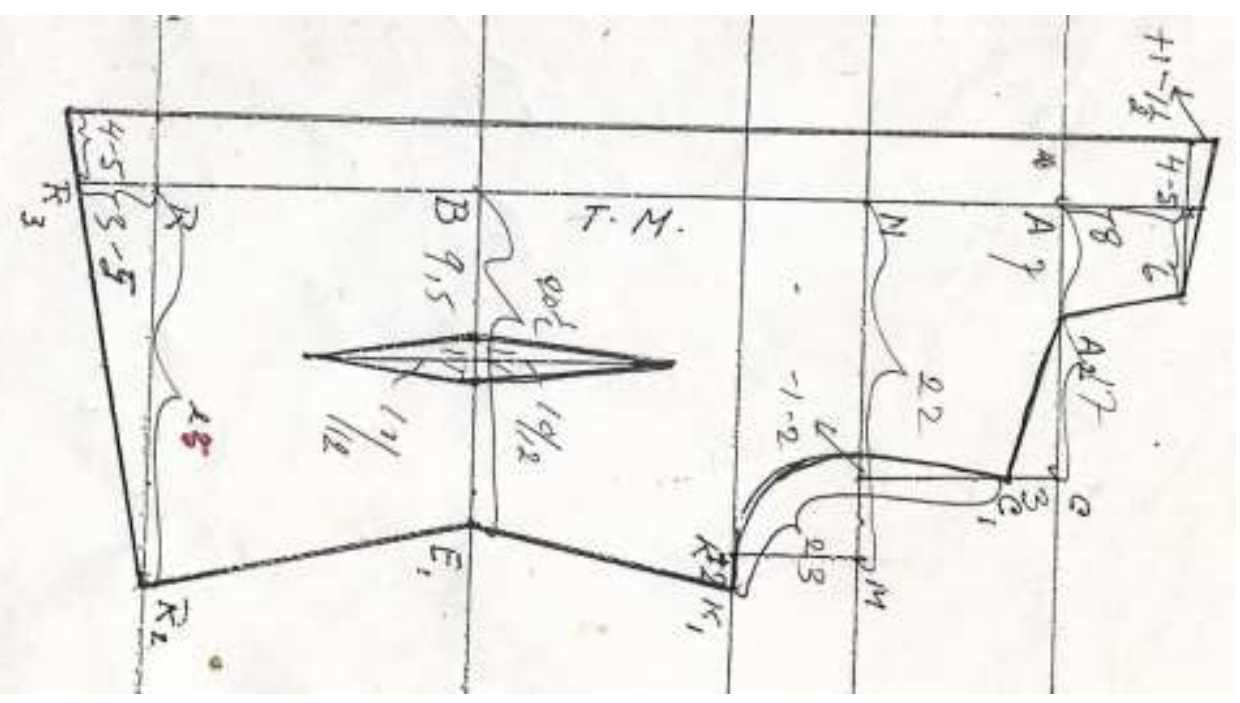

Figure 2. The pattern of the front

\section{To make pattern the hand (Figure 3):}

$\mathrm{A}-\mathrm{C}=$ the length of the hand

$\mathrm{A}-\mathrm{E}=8-10 \mathrm{~cm}$

$\mathrm{C}-\mathrm{D}=1 / 2 \mathrm{arm}$

$\mathrm{E}-\mathrm{B}=1 / 2$ armpit $-2 \mathrm{~cm}$

$\mathrm{A}-\mathrm{B}=1 / 2$ armpit

$\mathrm{B}-\mathrm{S} 1=1 / 3(\mathrm{~A}-\mathrm{B})$

$\mathrm{S} 1-\mathrm{S} 2=2 \mathrm{~cm}$

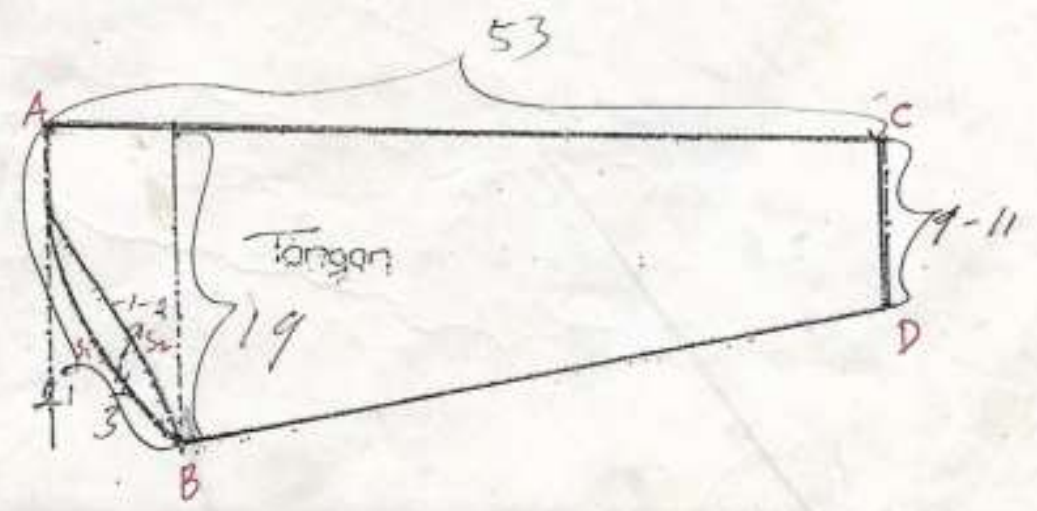

Figure 3. The Pattern the Hand 
In the design Kebaya Kartini to apply the concepts of mathematics including the number operations, plane, line, and angle. To make Kebaya Kartini pattern, it needs drawing skills and calculating skills. Drawing skills are need when drawing corners to begin drawing patterns. The calculating skills are need when calculating the size of the Kebaya Kartini pattern. The results are supported for several researches that stated that cultural as context would be important thing in learning process (Abdullah, 2017; Zaenuri \& Dwidayati, 2018; Ditasona, 2018; Hariastuti, 2017; Sari, et al. 2018; Putri, 2017; Wahyuni \& Pertiwi, 2017; Sudirman, et al. 2017; Pratikno, 2018; Muchsin, et al. 2014). Furthermore, the position in this research is to introduce Kebaya Kartini as a starting point in learning mathematics that has not been studied by previous researchers.

\section{CONCLUSION}

Ethnomathematics activity on the designing of Kebaya Kartini is very diverse. The process is starting from drawing angles, measure, and calculating the size of the pattern with the concept of integer operations. The culture is very important is embedded in students early on. Learning math based on culture can become a solution to introduce the culture and learning math. The result shows that in the activities of designing Kebaya Kartini have the concepts of mathematics, such as number operations, plane, line, and angle.

\section{REFERENCES}

Abdullah, A S. (2017). Ethnomathematics in perspective of Sundanese culture. Journal on Mathematics Education, 8(1), 1-6.

Anderson, S. E. (1990). World-math curriculum: Fighting eurocentrism in mathematics. Journal of Negro Education, 59(3), 348-359.

Arisetyawan, A., et al. (2014). Study of ethnomathematics: A lesson from the Baduy culture. International Journal of Education and Research, 2(10), 681688

Biembengut, M. S. (2016). Mathematical modelling, problem-solving, project, and ethnomathematics: Confluent points. Proceedings of the Birth Congress of the European Society for Research in Mathematics Education. 816820.

D'Ambrosio, U. (1989). On ethnomathematics. Philosophica Mathematica, 2(41), 3-14. 
Ditasona, C. (2018). Ethnomathematics exploration of the Toba community: Elements of geometry transformation contained in Gorga (Ornament on Batak House). Materials Science and Engineering: Conf. Series 338.

Fouze, A. Q., \& Amit, M. (2018). Development of mathematical thinking through integration of ethnomathematics folklore game in math instruction. EURASIA Journal of Mathematics, Science and Technology Education, 14(2), 617-630.

Gulo, W. (2000). Research Methodology. Jakarta: New Grasindo.

Hariastuti, R. M. (2017). Permainan tebak-tebak buah manggis: Sebuah inovasi pembelajaran matematika berbasis etnomatematika. Jurnal Matematika dan Pendidikan Matematika, 2(1), 25-35.

Haryanto, et. all. (2017). Ethnomathematics arfak (West Papua-Indonesia: Numeracy of Arfak. International Journal of Scientific \& Technology Research, 6(9), 325-327.

Kusuma, D. A., et al. (2016). The role of ethnomathematics in West Java (A preliminary analysis of case study in Cipatujah). Journal of Physics: Conf. Series 893.

Muchsin, S. B., Hartono, Y, \& Putri, R. I. I. (2014). Invented strategies for partitive division on fractions using duration context. Proceedings of The Second South East Asia Development Research Conference (pp. 308-317).

Muhtadi, D., Sukirwan, Warsito, \& Prahmana, R. C. I. (2017). Sundanese ethnomathematics: Mathematical activities in estimating, measuring, and making patterns. Journal on Mathematics Education, 8(2), 185-198.

Niess, M. L. (2005). Preparing teachers to teach science and mathematics with technology: Developing a technology pedagogical content knowledge. Teaching and Teacher Education, 21(5), 509-523.

Prahmana, R. C. I. (2017). Design research (teori dan implementasinya: Suatu pengantar). Jakarta: Rajawali Pers.

Prahmana, R. C. I., \& Kusumah, Y. S. (2016). The hypothetical learning trajectory on research in mathematics education using research-based learning. Pedagogika, 123(3), 42-54. 
Prahmana, R. C. I., Zulkardi, \& Hartono, Y. (2012). Learning multiplication using Indonesian traditional game in third grade. Journal on Mathematics Education, 3(2), 115-132.

Pratikno, H. (2018). Etnomatematika pada bregada prajurit Keraton Yogyakarta. Prosiding Seminar Nasional Pendidikan Matematika Etnomatnesia.

Putri, L. I. (2017). Eksplorasi etnomatematika kesenian rebana sebagai sumber belajar matematika pada jenjang MI. Jurnal Pendidikan Dasar, IV(1), 2131.

Risdiyanti, I., \& Prahmana, R. C. I. (2017). Ethnomathematics: Exploration in Javanese culture. Journal of Physics, Conf. Series 943012032.

Rosa, M., at al. (2016). Current and future perspectives of ethnomathematics as a program, ICME-13 Topical Surveys.

Runisah, et al. (2017). Using the 5E learning cycle with metacognitive technique to enhance students' mathematical critical thinking skills. International Journal on Emerging Mathematics Education, 1(1), 87-98.

Sari, E. F. P., et al. (2018). Etnomatematika pada kebudayaan rumah adat Ogan Komering Ulu Sumatera Selatan. Journal of Medives, 2(1), 137-144.

Spradley, P. J. (2007). Metode etnografi. Yogyakarta: Tiara Wacana.

Sudirman, et al. (2017). Penggunaan etnomatematika pada karya seni batik Indramayu dalam pembelajaran geometri transformasi. Pedagogy: Journal of Mathemathics Education, 2(1), 74-85.

Tanujaya, B., Prahmana, R. C. I., \& Mumu, J. (2017). Mathematics instruction, problems, challenges, and opportunities: A case study in Manokwari Regency, Indonesia. World Transactions on Engineering and Technology Education, 15(3), 287-291.

Wahyuni, A., \& Pertiwi, S. (2017). Etnomatematika dalam ragam hias Melayu. Math Didactic: Jurnal Pendidikan Matematika, 3(2), 113-118.

Zaenuri \& Dwidayati, N. (2018). Exploring ethnomathematics in Central Java. Journal of Physics: Conf. Series, 983. 